\title{
The inhibitory effect of Echinacea purpurea and Echinacea pallida on BT-549 and natural killer cells
}

\begin{abstract}
Background: Echinacea is a plant that has been widely used for its' medicinal properties, which include antioxidant properties, immune-stimulant, and anti-inflammatory properties. In this study, the effects of extracts of Echinacea pallida, Echinacea purpurea as well as the standard components of Echinacea were observed on a breast cancer cell line (BT-549). Also the effects of extracts of Echinacea pallida, Echinacea purpurea, and the standard components of Echinacea on natural killer cells were studied.

Methods: The anti-tumor activity of an organic extract of E pallida, organic extracts of E purpurea, and water soluble extracts of E purpurea as well as the standard components of Echinacea were evaluated in vitro on BT-549. In addition, the effect of the function of natural killer cells was determined after exposure to organic extracts of $E$ pallida, water soluble extracts of E purpurea and the standard components of Echinacea.

Results: A crude extract of E pallida, crude extracts of $E$ purpurea, water soluble extracts of E purpurea, and a standard components kit of Echinacea all exhibited cytotoxic activity against BT-549. Also, a crude extract of $E$ pallida, two dilutions of crude extracts of $E$ purpurea, water soluble extracts of E purpurea, and a standard components kit of Echinacea had no effect on the viability of natural killer cells. A water soluble extract of $E$ purpurea root and a standard components kit of Echinacea had no significant effect on the function of NK cells. However, one dilution of the crude extract of $E$ pallida, two dilutions of the crude extracts of E purpurea, and one water soluble extract of $E$ purpurea had an effect on the function of the NK cells.

Conclusion: This study supports the current research articles that have indicated the antitumor effect of extracts of E pallida and E purpurea on another breast cancer cell line, MCF-7. Further studies in vitro with Echinacea are needed to determine if this study supports a recent study that indicated an increase in the cytotoxicity of natural killer cells that are exposed to Echinacea.
\end{abstract}

Keywords: echinacea, anti-cancer, cytotoxic activity, etoposide, teniposide
Volume 4 Issue 3 - 2017

\author{
Steffani N Driggins, ' Margaret Whalen, ${ }^{2} \mathrm{E}$ \\ Lewis Myles' \\ 'Department of Biological Sciences, Tennessee State University, \\ USA \\ ${ }^{2}$ Department of Chemistry, Tennessee State University, USA
}

Correspondence: Lewis Myles E, Department of Biological Sciences, Tennessee State University, USA,

Email emyles@Tnstate.edu

Received: May 04, 2017| Published: July 18, 2017

\section{Background}

Phytochemicals have been used over centuries for their inherent potential to cure disease, as demonstrated by ancient medicinal practices. $^{1-4}$ Several plants have been shown to be sources of therapeutically important agents, which is valuable in the treatment of cancer. For example, there are very effective cancer chemotherapeutic drugs that have been derived from a natural origin. ${ }^{5}$ The naturally derived chemotherapeutic drugs include the vinca alkaloids vinblastine and vincristine, which were isolated from the Madagascar periwinkle, Catharanthus roseus. ${ }^{6}$ Paclitaxel (Taxol), another naturally derived chemotherapeutic drug, was originally isolated from the bark of the Pacific yew tree from the Pacific Northwest, Taxus bre vifolia Nutt. ${ }^{7}$ The analogue of taxol, docetaxel, is also a chemotherapeutic drug. ${ }^{7}$ Etoposide and teniposide are chemotherapeutic drugs that were derived semi-synthetically from epipodophyllotoxin, an epimer of podophyllotoxin, and isolated from roots of Podophyllum species. ${ }^{8}$ In addition, another naturally derived chemotherapeutic drug, camptothecin, was isolated from the bark of Camptotheca acuminata Decent. This is a precursor to the semi-synthethetic drugs topotecan (Hycamptin) and irinotecan (Camptosar). ${ }^{9}$

Echinacea is a medicinal plant that belongs to the botanical family Asteraceae and consists of nine species. ${ }^{10}$ The different species of
Echinacea consists of herbaceous perennial plants that are indigenous to North America and have been traditionally used to treat various ailments. ${ }^{2}$ For instance, Echinacea has been used to treat snakebites, syphilis, septic wounds, tonsillitis, periodontitis, viral infections, furunculosis, and nasopharyngeal catarrh. ${ }^{2}$ Echinacea is currently used for its' antioxidant properties, anti-inflammatory properties, and as an immunostimulant. ${ }^{11}$ As an immunostimulant, Echinacea is used in the prevention and treatment of the common cold, influenza and other respiratory tract infections. ${ }^{2}$ The common name for Echinacea is purple coneflower and it is characterized by a daisylike head that consists of several tiny flowers. 12 Echinacea purpurea, Echinacea angustifolia and Echinacea pallida are the three species of Echinacea that are primarily used medicinally, particularly the roots and rhizomes of the plants. Also, the flowering tops of E. purpurea are used medicinally. ${ }^{2}$ It has been note that commercial products of Echinacea contain up to $80 \%$ of E. Purpurea. ${ }^{13}$ The commercial products of Echinacea include tinctures, teas, beverages, powders, tablets, capsules and personal care products. ${ }^{13}$

The chemical components of Echinacea have been identified and isolated by HPLC analysis. The components have been identified as arabinogalactan, xyloglycan, echinacin, insulin, caffeic acid, caftaric acid, chicoric acid, echinacoside, cynarin, chlorogenic acid, isotussilagine, tussilagine, echinacin, isobutyl amides, polyacetylenes, 
polyenes terpenoids, fatty acids, essential oils, and phytosterols. Studies have determined that the polysaccharides, flavonoids, chicoric acid, alkyl amides, polyacetylenes and essential oils have been noted as being the active components of Echinacea. ${ }^{14}$ A recent study analyzed the raw materials of E. purpurea, E. angustofolia and $E$. pallida using HPLC. The study indicated that the raw materials of $E$. purpurea (roots, and aerials) contained caftaric acid, chlorogenic acid, and chicoric acid. However, the raw materials of E. angustofolia root contained caftaric acid, chlorogenic acid, cynarin, echinacoside and chicoric acid. The aerial raw materials of E. angustofolia, on the other hand, contained caftaric acid, echinacoside, and chicoric acid. Lastly, the study indicated that the raw materials of E. pallida root contained caftaric acid, echinacoside, and chicoric acid. ${ }^{13}$ An earlier study stated that the aerial parts of E. pupurea and E. angustofolia root also contain alkamides, polysaccharides, and polyacetylenes. The study stated that E. pallida root contains polysaccharides and polyacetylenes as well. ${ }^{1}$

Among the various chemical components of Echinacea, cynarin is found only in E. angustifolia, echinacoside is found primarily in $E$. pallida, and chicoric acid is found mainly in the roots as well as the flowers of E. Purpurea. ${ }^{12}$ Also, echinacin is found in the roots of $E$. pallida and E. angustifolia. Moreover, polyacetylenes and polyenes are the major lipophilic constituents of E. pallida roots. In addition, the isobutyl amides are found in high concentrations in the roots of $E$. angustifolia and E. Purpurea. ${ }^{10}$ Echinacea has been found to be the most common herbal supplement that is used by cancer patients. ${ }^{15}$ It was the second most popular herbal supplement among the cancer patients in a phase I clinical trial.15 An in vitro cancer study indicated that the treatment of hexane fractions, $\mathrm{CH} 2 \mathrm{Cl} 2$ (acidic fraction), and $\mathrm{CH} 2 \mathrm{Cl} 2$ fraction of Echinacea decreased the proliferation of a breast cancer cell line, MCF-7. Treatment of an AcOET fraction of Echinacea, however, increased the proliferation rate of the cells by $20-25 \%$. Also, there was an increase in the growth of the MCF-7 cells by $10-15 \%$ after treatment with chicoric acid but the growth of the cells decreased at the highest concentration of chicoric acid. The study indicated that cynarin, a phenolic compound obtained from the roots of $E$. angustifolia, displayed anti-proliferative activity on MCF-7 as well. It enhanced the cytotoxic activity of doxorubicin, an anticancer drug, against the MCF-7 cells. A more recent cancer study indicated that pentadeca-(8Z,13Z)-dien-11-yn-Z-one, a ketopolyacetylene derived from the root of $E$. pallida, exhibited anti-tumor activity on a breast cancer cell line (MCF-7). ${ }^{11}$

In vitroand In vivo studies of Echinacea and NK cells have been conducted as well. An in vitro study indicated that water soluble extracts of Echinacea activated the cytotoxicity of NK cells. ${ }^{16}$ An in vivo study indicated that extracts of E. angustifolia, E. pallida and E. purpurea that were orally administrated to normal mice, increased the cytotoxicity of natural killer cells in the mice. ${ }^{17}$ Another in vivo study noted that an increased number of natural killer cells, microscopic absence of tumor re-growth, and a prolonged life span in leukemic mice that were administered E. Purpurea ${ }^{18}$ In the current study, the effects of the crude extracts of E. pallida and E. purpurea root, and $E$. purpurea leaf on a breast cancer cell line (BT-549) are observed. Also, the effects of a water soluble extract of $E$. purpurea root, water soluble extract of $E$. purpurea leaf on BT-549 and a standard components kit of Echinacea on BT-549 are observed. In addition, the effects of the crude extract of E. pallida, crude extract of E. purpurea root, crude extract of E. purpurea leaf, water soluble extract of E. purpurea root, water soluble extract of $E$. purpurea leaf and the standard components kit of Echinacea on the viability as well as the function of natural killer cells were observed.

\section{Methods}

\section{Crude extracts of Echinacea purpurea and Echinacea pallida}

The leaves of E. pallida, roots of E purpurea, and the leaves of E purpurea were obtained from the campus green house and surface sterilized. The excess liquid was allowed to dry and placed in a freezer at $-70^{\circ} \mathrm{C}$ for 24 hours. The roots and leaves were removed from the freezer and grinded, separately, with a mortar and pestle. The grounded roots and leaves were placed in a Soxhlet, which contained Methanol. The crude extract was then placed on a Rotary Evaporator to remove the Methanol. The dissolved constituents were further dried under pressurized vacuum conditions. Stock solutions were prepared by dissolving the dried residue in Dimethyl sulphoxide (DMSO). Extract solutions were stored at $-20^{\circ} \mathrm{C} .{ }^{19-21}$

\section{Water soluble extracts of Echinacea purpurea}

The extraction of the water-soluble compounds used deionizerdistilled water. The roots of E purpurea and the leaves of $E$ purpurea were obtained from the greenhouse. Each sample was surface sterilized and rinsed three times with distilled water. Approximately $10 \mathrm{~g}$ of the samples were placed in a blender with $100 \mathrm{ml}$ of distilleddeionizer water. The samples were filtered with What man filters and stored in Lyophilization bottles. The bottles were frozen at $-70^{\circ} \mathrm{C}$ for twenty-four hours after which placed on lyophilize for 24 to 48 hours. The weight of the samples plus the bottles was taken before and after Lyophilization to obtain the weight of the sample/extract weight. The extract was dissolved in only enough deionizer-distilled water needed to solubilize the extract. The extract concentration is described as ug $\mathrm{ml}$. Extract solutions were stored at $-20^{\circ} \mathrm{C}$ until use.

\section{Standard components of Echinacea}

An Echinacea Complete Kit was obtained from Chromadex ${ }^{\circledR}$. The kit contained 10mg each of the following components of Echinacea: Caftaric acid, clonogenic acid, chicoric acid, cynarin, echinacoside and isobutyl amides.

\section{Breast cancer cells}

The breast cancer cell line that was used in the study was derived from human breast adenocarcinoma BT-549 (ATCC No. HTB-122) were provided by American Type Tissue Culture (Rockville, MD). The cell line was grown in RPMI-1640 and supplemented with $10 \%$ heat-inactivated fetal bovine serum (FBS), $2 \mathrm{mM} \mathrm{L-glutamine}$ and $1 \%$ penicillin-streptomycin. The cells were incubated in a $5 \% \mathrm{CO}_{2}$ humidified incubator at $37^{\circ} \mathrm{C}$ and passage bi-weekly.

\section{Isolation of natural killer cells}

The natural killer cells were derived from peripheral blood from healthy volunteer donors (male and female) was obtained from the Red Cross in Nashville, Tennessee. The donor blood was screened for blood type, hepatitis B, hepatitis C, HIV, syphilis, and cytomegalovirus. The donors were all negative for all infections with the exception of cytomegalovirus (approximately $40 \%$ of the donors were positive). Highly purified NK cells were obtained by using a resetting procedure. The Buffy coats were mixed with $1 \mathrm{~mL}$ of Rosettes human NK cell enrichment antibody cocktail (Stem Cell Technologies, Vancouver, BC, Canada) per $30 \mathrm{~mL}$ of Buffy coat. The mixture was incubated for 40 minutes at room temperature with periodic mixing. A fourmL of the mixture was layered onto $4 \mathrm{~mL}$ of Ficoll-Hypaque $(1.077 \mathrm{~g} / \mathrm{mL})$ (Sigma) and centrifuged at $1200 \mathrm{xg}$ for 
30minutes, after incubation. The cell layer was then collected and washed twice with PBS and stored in complete media at 1 million cells $/ \mathrm{mL}$. The cell preparation resulted in $>95 \% \mathrm{CD} 16+, 0 \% \mathrm{CD} 3+$ by fluorescence microscopy Whalen et al. ${ }^{25}$

\section{Trypan blue exclusion viability assay}

Anticancer activity was determined using this assay to measure cell viability. ${ }^{10}$ BT-549 cell line was plated at a density of $3 \times 10^{5}$ per well in 6-well tissue culture plates. The cells were incubated at $37^{\circ} \mathrm{C}$ and $5 \% \mathrm{CO}_{2}$ for $24 \mathrm{~h}$, after which the cells received treatment with fresh medium that was supplemented with one of the following: crude E pallida leaf extract, crude $E$ purpurea root extract, crude $E$ purpurea leaf extract, water soluble $E$ purpurea root extract, water soluble $E$ purpurea leaf extract, or the standard components kit of Echinacea. The concentrations of each extract were between $70 \mu \mathrm{g} / \mathrm{ml}-1750 \mu \mathrm{g} / \mathrm{ml}$. The negative controls received fresh medium supplemented with the experimental vehicle, DMSO only. Following $96 \mathrm{hr}$ of incubation at $37^{\circ} \mathrm{C}$, the cells were trypsinized with a $0.25 \%$ trypsin-EDTA solution. The cells were then resuspended in phosphate buffer saline (PBS) and stained with $0.4 \%$ trepan blue dye solution ( $\mathrm{v} / \mathrm{v}$ in PBS). Live cells are excluded from the stain while dead cells absorbed the stain appearing blue in color under a light microscope, enabling the enumeration of viable cells. Cell counts were expressed as mean \pm standard deviation (SD), representative of four separate experiments.

\section{Cytotoxicity assay for natural killer cells}

This assay was fused to determine the effects of the organic extracts of E pallida and E purpurea well as the effects of the water soluble extracts of $E$ purpurea and the standard components kit of Echinacea. NK cells were incubated with a dilution of one of the following: appropriate control, organic extract of $E$ pallida leaf, organic extract of $E$ purpurea root, organic extract of $E$ purpurea leaf, water soluble extract of $E$ purpurea root, water soluble extract of $E$ purpurea leaf or the standard components of Echinacea in a $12 \times 75$ tube. The dilutions consisted of the following range: 1/420-1/6720. NK-susceptible K562 (Human Chronic Myelogenous Leukemia) cell line (ATCC, Manassas, VA) were the target cells in this cytotoxicity assay. K562 cells ( 3 million) were incubated with $50 \mu \mathrm{Ci} 51 \mathrm{Cr}$ in $0.3-$ $0.5 \mathrm{~mL}$ of BCS for $1.5 \mathrm{~h}$ at $37^{\circ} \mathrm{C}$ in air $/ \mathrm{CO}_{2}$. After incubation, the target cells were washed twice in cell culture media. NK (effector) cells were added to the wells of round-bottom micro titer plates. The NK (effector) cells were diluted to $25: 1$ ratio $(2.5 \times 105$ per $100 \mu \mathrm{L}), 12.5: 1$ ratio and $6: 1$ ratio $\left(1.25 \times 10^{5}\right.$ per $\left.100 \mu \mathrm{L}\right)$. Each ratio was tested in triplicate. Targets were added $\left(1 \times 10^{4}\right.$ per $\left.100 \mu \mathrm{L}\right)$ to each well, and the plate was centrifuged at $600 \mathrm{rpm}$ for $3 \mathrm{~min}$ and incubated for $2 \mathrm{~h}$ at $37^{\circ} \mathrm{C}$ (air/CO $, 19: 1$ ). The ratios for purified NK cells were 25:1, 12.5:1, $6: 1$ and $3: 1$. After incubation, a $0.1 \mathrm{~mL}$ aliquot of the supernatant was collected and counted for radioactivity for $60 \mathrm{~s}$ in a Packard COBRA gamma counter (Packard Instrument Co., Meriden, CT). Specific lysis was calculated as follow:

100x[(test c.p.m.- spontaneous c.p.m.)/(maximum c.p.m. spontaneous c.p.m.)].

The maximum release was produced by adding $100 \mu \mathrm{L}$ of $10 \%$ Triton X-100. The amount of natural killer cells present in each tube was counted as well, using trepan blue and a haemacytometer. The assay was conducted a minimum of four times using the cells from different donors. ${ }^{26}$

\section{Statistical analysis}

Quantitative values obtained per treatment were converted to percentage inhibition. Regression analysis was used to compute the inhibition concentration required to produce a $50 \%$ reduction in cell viability (IC50). Results were expressed as the mean \pm SD of values obtained in triplicate from three independent experiments. Statistical differences between correlated samples were evaluated using Student's t-test and noted to be significantly different where $\mathrm{p}<0.05$. Composite treatments were compared using one-way analysis of variances (ANOVA) and considered significantly different where probability values were found to be equal to or less than 0.05 .

\section{Results}

The results of the effect of a crude extract of E pallida leaf indicated that the extract decreased the proliferation of BT-549 (Figure 3) in comparison to the DMSO-control cells. The dosage range of the crude extract was $70 \mu \mathrm{g} / \mathrm{ml}$ to $700 \mu \mathrm{g} / \mathrm{ml}$, for $96 \mathrm{hr}$. The proliferation of the BT-549 cells decreased significantly starting at $350 \mu \mathrm{g} / \mathrm{ml}$ and continued to decrease as the concentration of the crude extract of $E$ pallida increased. The results also indicated that BT-549 cells that were treated with DMSO continued to proliferate as the concentration of DMSO increased. Cells were plated at $3 \wedge 5$ cells per well in a 6 -well plates and treated for $96 \mathrm{hr}$. Values are presented as means $(\mathrm{n}=3) \pm$ S.D. *Statistical difference $(\mathrm{p}<0.05)$.

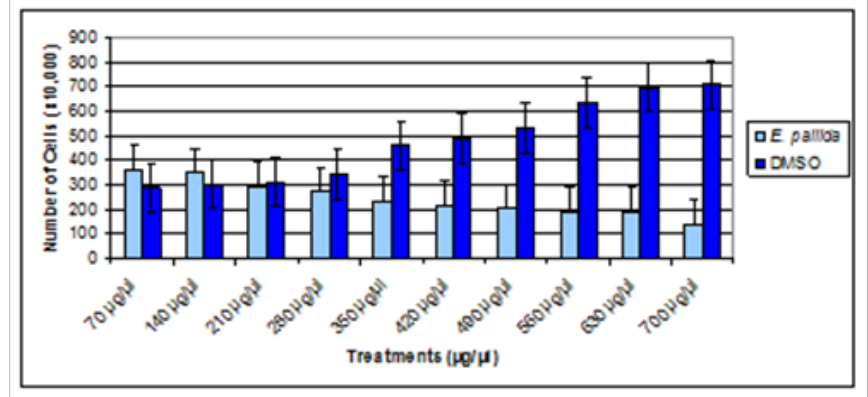

Figure I Time and dose response of organic extract of E. pallida leaf on cell proliferation of BT-549 cancer cell line.

The results of the effect of the organic extract of E purpurea root indicated that the extract decreased the proliferation of BT-549 (Figure 2) in comparison to the DMSO-control cells. The dosage range of the organic extract was $70 \mu \mathrm{g} / \mu \mathrm{l}$ to $700 \mu \mathrm{g} / \mu \mathrm{l}$, for $96 \mathrm{hr}$. The proliferation of the BT-549 cells decreased significantly starting at $280 \mu \mathrm{g} / \mu \mathrm{l}$ and continued to decrease as the concentration of the organic extract of E purpurea root increased. This is a lower dosage than the dosage from the organic extract of $E$ pallida leaf. The study indicated that the BT-549 cells that were treated with DMSO continued to proliferate as the concentration of DMSO increased as well. Cells were plated at $3 \wedge 5$ cells per well in a 6 -well plats and treated for $96 \mathrm{hr}$. Values are presented as means $(\mathrm{n}=3) \pm$ S.D. ${ }^{*}$ Statistical difference $(\mathrm{p}<0.05)$. The results of the effect of the organic extract of $E$ purpurea leaf indicated that the extract decreased the proliferation of BT-549 (Figure 3) in comparison to the DMSO-control cells. The dosage range of the organic extract was $70 \mu \mathrm{g} / \mu 1$ to $700 \mu \mathrm{g} / \mu 1$, for $96 \mathrm{hr}$. The proliferation of the BT-549 cells decreased significantly starting at $210 \mu \mathrm{g} / \mu \mathrm{l}$ and continued to decrease as the concentration of the organic extract of E purpurea leaf increased. This is a significantly lower dosage than the dosage from the organic extract of E pallida leaf. Moreover, the study indicated that the BT-549 cells that were treated with DMSO continued to proliferate as the concentration of DMSO increased.

Cells were plated at $3 \wedge 5$ cells per well in a 6 -well plats and treated for $96 \mathrm{hr}$. Values are presented as means $(\mathrm{n}=3) \pm$ S.D. * Statistical 
difference $(\mathrm{p}<0.05)$. The results of the effect of the water soluble extract of E purpurea root indicated that the extract decreased the proliferation of BT-549 (Figure 4) in comparison to the DMSO control cells. The dosage range of the water soluble extract was $70 \mu \mathrm{g} / \mu 1$ to $17500 \mu \mathrm{g} / \mu \mathrm{l}$, for $96 \mathrm{hr}$. The proliferation of the BT-549 cells decreased starting at $70 \mu \mathrm{g} / \mu \mathrm{l}$ and continued to decrease as the concentration of the water soluble extract of E purpurea root increased. However, the proliferation of the cells also decreased as the concentration of the control increased.

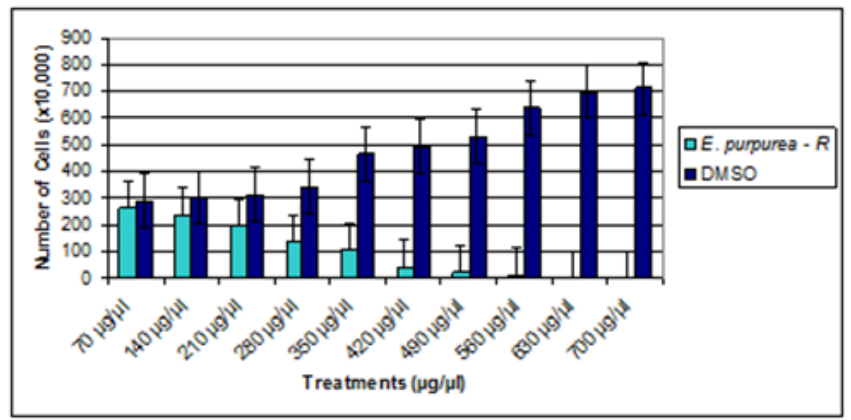

Figure 2 Time and dose response of the organic extract of $E$. purpurea root on cell proliferation of BT-549 cancer cell line.

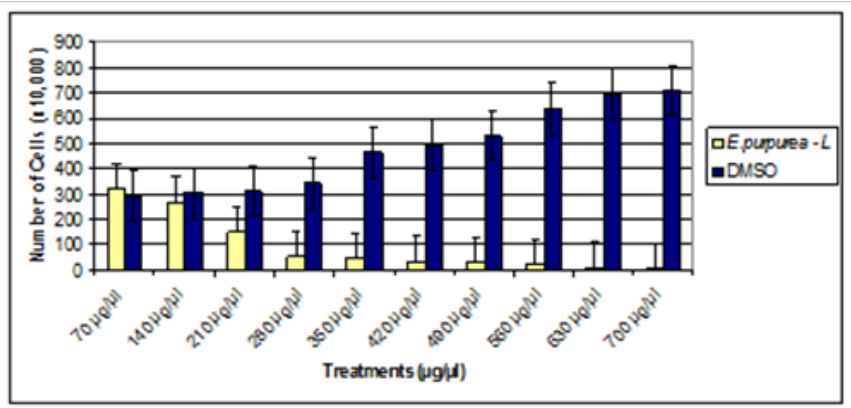

Figure 3 Time and dose response of organic extract of E. purpurea leaf on cell proliferation of BT-549 breast cancer cell line.

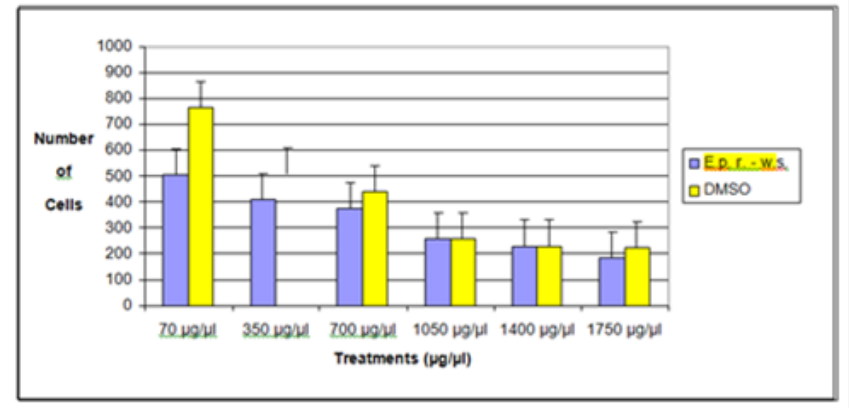

Figure 4 Time and dose response of water soluble extract of E. purpurea root on cell proliferation of BT-549 breast cancer cell line.

Cells were plated at $3 \wedge 5$ cells per well in a 6 -well plats and treated for $96 \mathrm{hr}$. Values are presented as means $(\mathrm{n}=3) \pm$ S.D. *Statistical difference $(p<0.05)$. The results of the effect of the water soluble extract of E purpurea leaf indicated that the extract decreased the proliferation of BT-549 (Figure 5). The dosage range of the water soluble extract was $70 \mu \mathrm{g} / \mu \mathrm{l}$ to $17500 \mu \mathrm{g} / \mu \mathrm{l}$, for $96 \mathrm{hr}$. The proliferation of the BT-549 cells decreased starting at $70 \mu \mathrm{g} / \mu 1$ in comparison to the DMSO control cells. The proliferation of the cells continued to decrease as the concentration of the water soluble extract of $E$ purpurea leaf increased. However, the proliferation of the cells also decreased as the concentration of the control increased. Cells were plated at $3 \wedge 5$ cells per well in a 6 -well plats and treated for $96 \mathrm{hr}$. Values are presented as means $(n=3) \pm$ S.D. *Statistical difference $(p<0.05)$. The results of the effect of the standard components of Echinacea indicated that the extract decreased the proliferation of BT-549 (Figure 6). The dosage range of the standard components was $70 \mu \mathrm{g} / \mu 1$ to $1750 \mu \mathrm{g} / \mu \mathrm{l}$, for $96 \mathrm{hr}$. The proliferation of the BT-549 cells decreased significantly starting at $700 \mu \mathrm{g} / \mu \mathrm{l}$. The standard components of Echinacea continued to decrease the proliferation of BT-549 as the concentration of the standard components increased, in comparison to the DMSO control cells. In addition, the proliferation of the DMSO control cells increased as the concentration of DMSO increased.

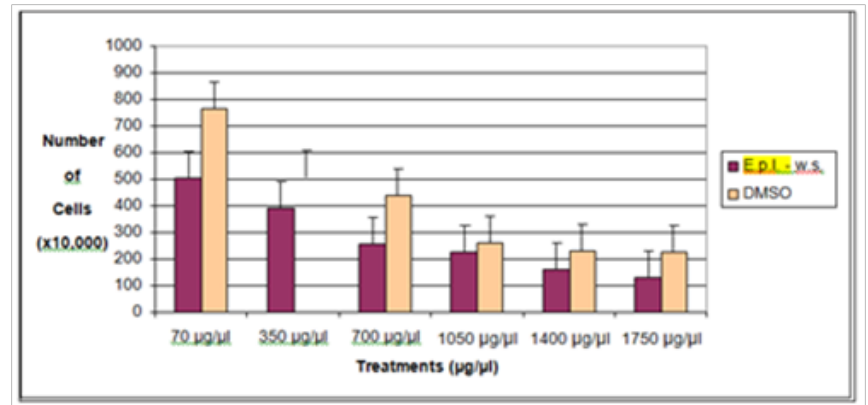

Figure 5 Time and dose response of water soluble extract of $E$. purpurea leaf on cell proliferation of BT-549 breast cancer cell line.

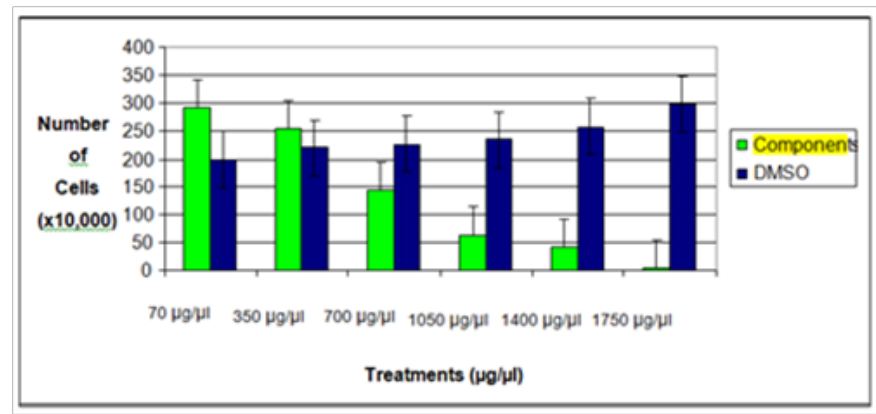

Figure 6 Time and dose response of standard components of Echinacea on cell proliferation of BT-549 cancer cell line.

Cells were plated at $3 \wedge 5$ cells per well in a 6 -well plats and treated for $96 \mathrm{hr}$. Values are presented as means $(\mathrm{n}=3) \pm$ S.D. *Statistical difference $(p<0.05)$. The results of the effect of an organic extract of E pallida leaf on natural killer cells indicated that the viability (not shown) of the natural killer cells were not affected. The NK cells were treated with dilutions of the organic extract that consisted of $1 / 1840$, $1 / 1680$, and $1 / 6720$ for $24 \mathrm{hr}$. The results also indicated that the organic extract decreased the ability of the NK cells to lyse the target cell significantly for the 1/840 dilution, in comparison to the DMSO control cells (Table 1). The effect of the extract on the cytotoxicity of the natural killer cells for the 1/1680 and 1/6720 dilutions are not as significant in comparison to the control. Data are mean \pm S.D. from triplicate determinations, $\mathrm{n}=3$. Table 1 shows the effect of $24 \mathrm{hr}$ exposure to dilutions of organic extract of $E$ pallida leaf. The results of the effect of water soluble extract of $E$ purpurea root on natural killer cells indicated that the viability (not shown) of the natural killer cells were not affected. The results indicated that the extract had no effect on the cytotoxicity of the natural killer cells, in comparison to the DMSO control cells (Table 2) as well.

Data are mean \pm S.D. from triplicate determinations, $n=3$. Table 2 
shows the effect of the standard components of Echinacea on natural killer cells after $24 \mathrm{hr}$. The results of the effect of water soluble extract of E purpurea leaf on natural killer cells indicated that the viability (not shown) of the natural killer cells were not affected. Also, the results indicated that the extract significantly affected the cytotoxicity of the natural killer cells, in comparison to the DMSO control cells (Table 3). Data are mean \pm S.D. from triplicate determinations, $n=3$. Table 3 shows the effect of the standard components of Echinacea on natural killer cells after $24 \mathrm{hr}$. The results of the effect of the standard components of Echinacea on natural killer cells indicated that the indicated that the viability (not shown) of the natural killer cells were not affected. Also, the standard components did not significantly affect the cytotoxicity of the natural killer cells, in comparison to the DMSO control cells (Table 4). Data are mean \pm S.D. from triplicate determinations, $n=3$. Table 4 shows the effect of the standard components of Echinacea on natural killer cells after $24 \mathrm{hr}$. Data are mean \pm S.D. from triplicate determinations, $n=3$. Table 5 shows the effect of the water soluble extract of $E$ purpurea leaf on natural killer cells after $24 \mathrm{hr}$. The standard components kit of Echinacea had no effect on the viability of the natural killer cells (not shown). Also, the standard components had no significant effect on the cytotoxicity of the NK cells, in comparison to the DMSO control cells (Table 6).

Table I Cell Lysis Ability of Natural Killer Cellsto Lyse K562 Target Cells afterTreatment with Organic Extract of E. pallida Leaf

\begin{tabular}{lll}
\hline & Specific Lysis (\%) & Specific Lysis (\%) \\
\hline NK Cell:Target & Control (DMSO-24h) & E. pallida Leaf (I/840 dilution-24hr) \\
\hline I2:I & $73 \pm 7$ & $31 \pm 1$ I \\
$6: 1$ & $58 \pm 5$ & $27 \pm 10$ \\
$3: 1$ & $38 \pm 1$ & $15 \pm 5$ \\
\hline NK Cell:Target & Control (DMSO-24h) & E. pallida Leaf (I/I680 dilution-24hr) \\
\hline I2:I & $73 \pm 7$ & $54 \pm 5$ \\
6:I & $58 \pm 5$ & $46 \pm 7$ \\
3:1 & $38 \pm 1$ & $35 \pm 8$ \\
\hline NK Cell:Target & Control (DMSO-24h) & E. pallida Leaf (I/6720 dilution-24hr) \\
\hline I2:I & $63 \pm 3$ & $51 \pm 4$ \\
6:I & $49 \pm 1$ & $42 \pm 3$ \\
3:1 & $31 \pm 2$ & $27 \pm 2$ \\
\hline
\end{tabular}

Table 2 Cell Lysis Ability of Natural Killer Cellsto Lyse K562 Target Cells afterTreatment with a Water Soluble Extract of E. purpurea Root

\begin{tabular}{llll}
\hline & & Specific Lysis (\%) & Specific Lysis (\%) \\
\hline NK Cell:Target & Dilution & Control (DMSO - 24 hr) & E. purpurea Root (24 hr) \\
\hline 12:1 & $350 \mu \mathrm{L}$ & $73 \pm 5$ & $70 \pm 3$ \\
6:1 & $350 \mu \mathrm{L}$ & $65 \pm 3$ & $64 \pm 2$ \\
3:1 & $350 \mu \mathrm{L}$ & $49 \pm 3$ & $54 \pm 4$
\end{tabular}

Table 3 Cell Lysis Ability of Natural Killer Cellsto Lyse K562 Target Cells after Treatment with a Water Soluble Extract of E. purpurea Leaf

\begin{tabular}{llll}
\hline & & Specific Lysis (\%) & Specific Lysis (\%) \\
\hline NK Cell:Target & Dilution & Control (DMSO - 24 hr) & E. purpurea Leaf (24 hr) \\
\hline 12:1 & $350 \mu \mathrm{L}$ & $73 \pm 5$ & $20 \pm 2$ \\
$6: 1$ & $350 \mu \mathrm{L}$ & $65 \pm 3$ & $15 \pm 1$ \\
$3: 1$ & $350 \mu \mathrm{L}$ & $49 \pm 3$ & $9 \pm 1$ \\
\hline
\end{tabular}

Table 4 Cell Lysis Ability of Natural Killer Cellsto Lyse K562 Target Cells after Treatment with Echinacea Standard Components

\begin{tabular}{llll}
\hline & & Specific Lysis (\%) & Specific Lysis (\%) \\
\hline NK cell: target & Dilution & Control (DMSO- 24 hr) & Echinacea Components (24 hr) \\
\hline I2:I & $350 \mu \mathrm{L}$ & $73 \pm 5$ & $67 \pm 2$ \\
$6: 1$ & $350 \mu \mathrm{L}$ & $65 \pm 3$ & $55 \pm 1$ \\
$3: 1$ & $350 \mu \mathrm{L}$ & $49 \pm 3$ & $36 \pm 1$ \\
\hline
\end{tabular}


Table 5 Cell Lysis Ability of Natural Killer Cells to Lyse K562 Target Cells after Treatment with a Water Soluble Extract of E. purpurea Leaf

\begin{tabular}{llll}
\hline & & Specific lysis (\%) & Specific lysis (\%) \\
\hline NK Cell:Target & Dilution & Control (DMSO - 24 hr) & E. purpurea Leaf (24 hr) \\
\hline 12:1 & $350 \mu \mathrm{L}$ & $73 \pm 5$ & $20 \pm 2$ \\
$6: 1$ & $350 \mu \mathrm{L}$ & $65 \pm 3$ & $15 \pm 1$ \\
$3: 1$ & $350 \mu \mathrm{L}$ & $49 \pm 3$ & $9 \pm 1$ \\
\hline
\end{tabular}

Table 6 Cell Lysis Ability of Natural Killer Cells to Lyse K562 Target Cells After Treatment with Standard Components Kit of Echinacea Data are mean \pm S.D. from triplicate determinations, $n=3$

\begin{tabular}{llll}
\hline & & Specific lysis (\%) & Specific lysis (\%) \\
\hline NK cell: target & Dilution & Control (DMSO-24hr) & Echinacea Components (24hr) \\
\hline I2:I & $350 \mu \mathrm{L}$ & $73 \pm 5$ & $67 \pm 2$ \\
$6: 1$ & $350 \mu \mathrm{L}$ & $65 \pm 3$ & $55 \pm 1$ \\
$3: 1$ & $350 \mu \mathrm{L}$ & $49 \pm 3$ & $36 \pm 1$ \\
\hline
\end{tabular}

\section{Discussion}

The first aim of the study was to observe the effects of a crude extract of $E$ pallida leaf, crude extract of $E$ purpurea root, and a crude extract of E purpurea leaf on BT-549. The second aim of the study was to determine the effects of a water soluble extract of $E$ purpurea root and a water soluble extract of E purpurea leaf on BT-549. The third aim of the study was to determine the effects of a standard components kit of Echinacea on a breast cancer cell line, BT-549. The fourth aim of the study was to observe the effects of a crude extract of $E$ pallida leaf, crude extract of E purpurea root, crude extract of $E$ purpurea leaf, water soluble extract of $E$ purpurea root, water soluble extract of E purpurea leaf as well as a standard components kit of Echinacea on natural killer cells. The results of the first aim of the study indicated that the crude extract of E pallida leaf, crude extract of E purpurea root, and the crude extract of E purpurea leaf significantly decreased the growth of a breast cancer cell line (BT-549), in comparison to the DMSO control cells. The dosage range of the crude extracts was $70 \mu \mathrm{g} / \mathrm{ml}$ to $700 \mu \mathrm{g} / \mathrm{ml}$, for $96 \mathrm{hr}$. The crude extract of $E$ pallida started decreasing the proliferation of BT-549 at $350 \mu \mathrm{g} / \mathrm{ml}$ (Figure 3) and continued to decrease as the concentration increased $(\mathrm{IC} 50=420 \mu \mathrm{g} / \mathrm{ml})$. The proliferation of the BT-549 cells, however, started to decrease significantly at $280 \mu \mathrm{g} / \mu \mathrm{l}$ for the crude extract of E purpurea root (Figure 4) and $210 \mu \mathrm{g} / \mathrm{ml}$ for the crude extract of $E$ purpurea leaf (Figure 5). The crude extracts of E purpurea root and E purpurea leaf continued to decrease the proliferation of BT-549 as the concentration of the extracts increased, with IC50=350 $\mu \mathrm{g} / \mathrm{ml}$ and IC $50=280 \mu \mathrm{g} / \mathrm{ml}$ respectively.

Since the crude extracts of $E$ purpurea had a more significant rate of anti-tumor activity on BT-549, the second aim of the study involved determining the effects of water soluble extracts of E purpurea root and E purpurea leaf on BT-549. Both water soluble extracts of $E$ purpurea significantly decreased the proliferation of BT-549. The dosage range of the water soluble extracts of E purpurea was $70 \mu \mathrm{g} / \mathrm{ml}$ to $1750 \mu \mathrm{g} /$ $\mu 1$, for $96 \mathrm{hr}$. The water soluble extract of E purpurea root (Figure 6) and the water soluble extract of $E$ purpurea leaf both decreased the proliferation of BT-549 at starting at $70 \mu \mathrm{g} / \mathrm{ml}$ (Figure 7). Also, both extracts of continued to decrease the proliferation of BT-549 as the concentration of the extracts increased (IC50 $=1050 \mu \mathrm{g} / \mathrm{ml})$. The third aim of the study used a standard components kit of Echinacea on BT-549. The kit consisted of caftaric acid, clonogenic acid, chicoric acid, cynarin, echinacoside and isobutyl amides that were suspended in water. The dosage range of the components was $70 \mu \mathrm{g} / \mathrm{ml}$ to $1750 \mu \mathrm{g} / \mathrm{ml}$, for $96 \mathrm{hr}$. The components significantly decreased the proliferation rate of BT-549 at $700 \mu \mathrm{g} / \mu 1$, in comparison to the DMSO control cells (Figure 8). Also, the components continued to decrease the proliferation of BT-549 as the concentration of the components increased $(\mathrm{IC} 50=1050 \mu \mathrm{g} / \mathrm{ml})$. In all, the standard components kit of Echinacea demonstrated anti-tumor activity against BT-549 just as the water soluble extracts of Echinacea demonstrated an anti-tumor activity against BT-549.

Only the 1/840 dilution of the crude extract of E pallida leaf decreased the ability of the NK cells to lyse the target cell significantly, in comparison to the DMSO control cells (Table 1). The decrease in cytotoxicity of the cells began at the 12:1 ratio and continued to decrease at the 6:1 as well as the 3:1 ratio. Unfortunately, the NK cells were dead after they were treated with $1 / 420$ and 1/840 dilutions of the crude extract of $E$ purpurea root. The 1/1680 and 1/3360 dilutions of the crude extract of $E$ purpurea root had no effect on the viability of the NK cells. However, the dilutions affected the cytotoxicity of the cells significantly, in comparison to the DMSO control cells (Table 2). The decrease in cytotoxicity of the cells began at the 12:1 ratio and continued to decrease at the $6: 1$ as well as the $3: 1$ ratio. The NK cells were also dead after they were treated with $1 / 420$ and $1 / 840$ dilutions of the crude extract of E purpurea leaf. The 1/1680 and 1/3360 dilutions of the crude extract of $E$ purpurea leaf had no effect on the viability of the NK cells but the cytotoxicity of the cells were effected significantly, in comparison to the DMSO control cells. The decrease in cytotoxicity of the NK cells began at the 12:1 ratio and continued to decrease at the $6: 1$ as well as the $3: 1$ ratio. The water soluble extract of E purpurea root had no effect on the viability of the NK cells and had no effect on the cytotoxicity of the cells, in comparison to the DMSO control cells (Table 2). The water soluble extract of E purpurea leaf had no effect on the viability of the NK cells but had a significant effect on the cytotoxicity of the cells, in comparison to the DMSO control cells (Table 3). The decrease in cytotoxicity began at the 12:1 ratio and continued to decrease at the $6: 1$ as well as the 3:1 ratio. Lastly, the standard components kit of Echinacea had no effect on the viability of the NK cells. It also had no significant effect on the cytotoxicity of the NK cells, in comparison to the DMSO control cells (Table 4). 


\section{Conclusion}

The study indicated that the crude extract of $E$ pallida, crude extracts of E purpurea, water soluble extracts of $E$ purpurea, and a standard components kit of Echinacea all exhibited cytotoxic activity against BT-549. Also, it was noted that the crude extract of E purpurea root and $E$ purpurea leaf exhibited anti-tumor activity against BT-549 at a lower dosage than $E$ pallida leaf. This could possibly be due to the chicoric acid, an active component of Echinacea that is primarily found in E purpurea, which has been noted for its' anti-tumor activity in another breast cancer cell line, MCF-7. ${ }^{23}$ In addition, it could be due to the isobutyl amides, other active components of Echinacea, which are present in E purpurea in high concentrations. ${ }^{11}$ Moreover, chicoric acid and the isobutyl amides could have been working synergistically, along with the other active components in the crude extracts of $E$ purpurea, against the proliferation of BT-549 in the study. In addition, the water soluble extracts of E purpurea root and E purpurea leaf exhibited anti-tumor activity against BT-549 at a lower dosage than the crude extracts of E purpurea root and E purpurea leaf. This is possibly due to the percentage of the unknown compounds in the crude extracts of E purpurea that may interfere with the anti-tumor activity of the known active components, in comparison to the water soluble extracts. Studies have determined that some of the other components of E purpurea include phenolic acids, butane, simple sugars, sterols and vanillin. ${ }^{2} \mathrm{HPLC}$ of the crude extracts of E purpurea could possibly indicate that the percentage of the unknown components in the crude extracts is greater than the percentage of the known components. This would support the results of the anti-tumor activity against BT-549 by the crude extracts in comparison to the anti-tumor activity of the water soluble extracts.

The experiments with the water soluble extract of the roots of $E$ purpurea also indicated that the cell proliferation of the breast cancer cells that were exposed to the control, Dimethyl sulfoxide, increased significantly. In addition, the experiments with the water soluble extract of the leaves of E purpurea indicated that the cell proliferation of the breast cancer cells that were exposed to $70 \mu \mathrm{g} / \mu 1,350 \mu \mathrm{g} / \mu \mathrm{l}$, and $700 \mu \mathrm{g} / \mu \mathrm{l}$ of DMSO increased significantly. Research was recently conducted that determined the effect of DMSO on myeloma cells and doxorubicin-resistant myeloma cells. The study indicated that low concentrations of DMSO increased the proliferation of the cells. The study also indicated that the proliferation of the cells was dosedependent and could result in a maximal 3.57 fold increase after being exposed to $0.2 \%$ of DMSO. ${ }^{27}$ Another study, determined the effects of DMSO on ovarian cancer cells (Caov-3, OVCAR-3, and SK-OV-3). The study indicated variability in the number of ovarian cancer cells treated with varying concentrations of DMSO in comparison to the control, which was the cell medium. The study indicated that cell proliferation increased among the ovarian cancer cells after they were treated with DMSO that was added to the medium as well [28]. In all, both studies provide a plausible explanation of the cell proliferation in the BT-549 cancer cells in the experiments with the water soluble extracts of E purpurea.

The study also noted that the crude extracts of E purpurea root and E purpurea leaf exhibited an anti-tumor activity against BT-549 at a lower dosage than the standard components kit of Echinacea. This could be due to the synergistic effect of unknown compounds in the crude extract, which are not present in the standard components kit of Echinacea. Also, the water soluble extracts of E purpurea root and E purpurea leaf exhibited an anti-tumor activity against BT-549 at a lower dosage than the standard components kit of Echinacea. This is possibly due to the synergistic effect of the known and unknown components in the water soluble extracts that were not in the standard components kit of Echinacea as well. The results of the first three aims of this study are quite significant because they support an anti-cancer study that determined a ketopolyacetylene, pentadeca(8Z,13Z)-dien-11-yn-Z-one, from the root of E pallida demonstrated anti-tumor activity against another breast cancer cell line, MCF-7. ${ }^{11}$ The results also supports the results of experiments that indicated chicoric acid decreased the growth of MCF-7 at high dosages as well. ${ }^{29}$ The cytotoxic effect of chicoric acid has been noted to reduce telomerase activity and induce apoptosis via DNA fragmentation in human colon cancer cells. ${ }^{30}$ Another study indicated that clonogenic acid caused apoptosis in leukemia cells (U937) through Caspase and mitochondria-dependent pathways. ${ }^{31}$ A study that involved liver cancer cells, indicated that chlorogenic acid enhanced the effects of 5-fluorouracil on the cancer cells, which resulted in a significant decrease in cell proliferation. ${ }^{18}$ These studies are significant because chicoric acid and clonogenic acid are components that are found in the roots of E purpurea as well. They could possibly be two of the components in the crude extract and water soluble extract of $E$ purpurea root that significantly reduced the growth of the BT-549 cells in the study. Lastly, the study supports the discovery of the antiproliferative activity of cynarin, found in E. pallida, against MCF-7 and its' enhancement of the cytotoxic activity of the chemotherapy drug doxorubicin on the MCF-7 cells. ${ }^{23}$

The results of the effects of the crude extract of E. pallida, crude extracts of $E$ purpurea, and the water soluble extracts of $E$ purpurea on the NK cells, do not support in vivo studies with Echinacea and NK cells. An in vivo study of oral administration of extracts of $E$ pallida and $E$ purpurea in normal mice indicated that the cytotoxicity of NK cells in mice was increased. ${ }^{31}$ Also, the results do not support an in vitro study that indicated that water soluble extracts of Echinacea activated the cytotoxicity of the NK cells. ${ }^{16}$ The current study, however, supports an in vitro study that exposed NK cells to a series of concentrations of Echinacea and noted that cytotoxicity activity of the cells through the synthesis of granzyme B was not observed. ${ }^{33}$ It supported another in vivo study that did not observe an altered NK cell activity in rats that were fed a commercial Echinacea product as well. ${ }^{34}$ In all, in vitro studies of the effects of crude and water soluble extracts of E pallida leaf and E pallida root on BT-549 are needed. Moreover, in vitro studies of the effects of crude and water soluble extracts of E pallida on other breast cancer cell lines are needed. In addition, in vitro studies of the effects of crude and water soluble extracts of $E$ purpurea on other breast cancer cells lines are needed. Also, HPLC analysis of the crude and water soluble extracts of $E$ pallida leaf, $E$ purpurea root, E purpurea leaf is needed to determine the percentages of each known component and unknown components of the extracts. Furthermore, in vitro studies are needed need to determine which component or components of Echinacea demonstrate anti-tumor activity against BT-549 and other breast cancer cell lines. In vitro studies need to be conducted on the effects of crude and water soluble extracts of $E$ pallida root on NK cells as well. The results could be used in further in vivo studies with extracts of Echinacea with NK cells on normal and breast cancer tumor models.

\section{Acknowledgements}

We are thankful to the U.S. Department of Education Title III Grant, Tennessee State University, for the financial support. 


\section{Funding} Grant.

Funding was provided by U.S. Department of Education Title III

\section{Authors' contributions}

SND and ELM conceived and designed the experiments. ELM obtained and prepared the plants. ELM prepared the crude and water soluble extracts of the plants. SND performed the cell assay experiments with BT-549 and analyzed the data. MW performed the natural killer cytotoxicity assay and analyzed the data. SND wrote the paper. ELM supervised the study and revised the manuscript. All authors read and approved the final version of the manuscript to be published.

\section{Competing interests}

The authors declare that they have no competing interests.

\section{References}

1. Barnes J. Herbal therapeutics (7) Colds. Pharm J. 2002;269:716-718.

2. Barnes J, Anderson LA, Gibbons S, et al. Echinacea species (Echinacea angustifolia (DC.) Hell, Echinacea pallida (Nutt.) Nutt., Echinacea purpurea (L.) Moench): a review of their chemistry, pharmacology and clinical properties. J Pharm Pharmocol. 2005;57(8):929-954.

3. Barrett B. Medicinal properties of Echinacea: a critical review. Phytomedicine. 2003;10(1):66-86.

4. Baselga J. Combined anti-egf receptor and anti-her2 receptor therapy in breast cancer: a promising strategy ready for clinical testing. Ann Oncol. 2002;13:8-9.

5. Baum BR, Mechanda S, Livesey JF, et al. Predicting quantitative phytochemical markers in single Echinacea plants or clones from their DNA fingerprints. Phytochemistry. 2001;56(6):543-549.

6. Bernstein BB, Grasso T. Prevalence of Complementary and Alternative Medicine Use in Cancer Patients. Oncology. 2001;15(10):1267-1272.

7. Binns, SE, Purgina B, Bergeron $\mathrm{C}$, et al. Light-mediated antifungal activity of Echinacea extracts. Planta Med. 2000;66(3):241-244.

8. Binns S, Hudson J, Merali S, et al. Antiviral activity of characterized extacts from Echinacea spp. (heliantheae: astraceae) against herpes simplex virus (hsv-1). Planta Med. 2002;68(9):780-783.

9. Brousseau M, Miller S. Enhancement of natural killer cells and increased survival of aging mice fed daily Echinacea root extract from you. Biogerontology. 2005;6(3):157-163.

10. Goldhaber-Fiebert S, Kemper K. Echinacea: e. angustifolia, e. pallida, and e. purpurea. The Center for Holistic Pediatric Education and Research. 1999:1-24.

11. Chica A, Adinolfi B, Pellati F, et al. Cytotoxic activity and G1 cell cycle arrest of a Dienynone from Echinacea pallida. Planta Med. 2010;76(5):444-446.

12. McKeown K. A review of the taxonomy of the genus Echinacea. In: Janick J, editor. Perspectives on New Crops and New Uses. USA: ASHS Press; 1999. p. 482-489.

13. Brown P, Chan M, Paley L, et al. Determination of Major Phenolic Compounds in Echinacea spp. Raw Materials and Finished Products by High-Performance Liquid Chromatography with Ultraviolet Detection: Single Laboratory Validation Matrix Extension. J AOAC Int. 2011;94(5):1400-1410.

14. Kumar KM, Sudha Ramaiah S. Pharmacological importance of Echinacea purpurea. International Journal of Pharma and Bio Sciences. 2011;2(4):304-314.
15. Goey A. Clinical Pharmacokinetic Interactions between Herbal Supplements and Anticancer Drugs: The effect of Echinacea purpurea on the pharmacokinetics of docetaxel. The Netherlands: Utrecht University; 2013. p. $85-100$.

16. Gan XH, Zhang L, Heber D, et al. Mechanism of activation of human peripheral blood NK cells at the single cell level by Echinacea water soluble extracts: recruitment of lymphocyte-target conjugates and killer cells and activation of programming for lysis. International Immunopharmacology. 2003;3(6):811-824.

17. Whalen M, Loganthan B, Kannan K. Immunotoxicity of environmentally relevant concentrations of butyl tins on human natural killer cells in vitro. Environ Res. 1999;81(2):108-116.

18. Currier N, Miller S. Echinacea purpurea and melatonin augment naturalkiller cells in leukemic mice and prolong life span. J Altern Complement Med. 2001;7(3):241-251.

19. Olayinka A Aiyegoro, Anthony I Okoh. Preliminary phytochemical screening and In vitro antioxidant activities of the aqueous extract of Helichrysum longifolium DC. BMC Complement Altern Med. 2010;10:21.

20. Saudat Adamson Fadeyi, Olugbeminiyi O Fadeyi, Adedeji A Adejumo, et al. In vitro anticancer screening of 24 locally used Nigerian medicinal plants. BMC Complement Altern Med. 2013;13:79.

21. See DM, Broumand N, Sahl L, et al. In vitro effects of Echinacea and ginseng on natural killer and antibody-dependent cell cytotoxicity in healthy subjects and chronic fatigue syndrome or acquired immunodeficiency syndrome patients. Immunopharmacology. 1997;35:229-235.

22. Oxana V Kharissova, Rasika Dias HV, Boris I Kharisov, et al. Green Synthesis Of Silver Nanoparticles Using Artocarpus Heterophyllus Lam. Seed Extract And Its Antibacterial Activity. Industrial Crops and Products. 2013;46:132-137.

23. D Markin, L Duek, I Berdicevsky. In vitro antimicrobial activity of olive leaves. Mycoses. 2003;46:3-4.

24. Leigh Broadhurst, Marilyn M Polansky, Richard A Anderson. Insulinlike Biological Activity of Culinary and Medicinal Plant Aqueous Extracts in Vitro. J Agric Food Chem. 2000;48(3):849-852.

25. Wen J, Tong Y, Zu Y. Low Concentration DMSO Stimulates Cell Growth and In vitro Transformation of Human Multiple Myeloma Cells. BJMMR. 2015;5(1):65-74.

26. Strober W. Trypan blue exlusion test of cell viability. Curr Protc Immun. 1997;3:1-2.

27. Sun L, Currier N, Miller S. The American coneflower: a prophylactic role involving nonspecific immunity. $J$ Altern Complement Med. 1999;5(5):437-446.

28. Buford-Rodriquez C, Talley L, Barnes MN, et al. The use of dimethylsulfoxide as a vehicle in cell culture experiments using ovarian carcinoma cell lines. Biotech Histochem. 2003;78(1):17-21.

29. Huntimer ED, Halaweish FT, Chase CCL. Proliferative activity of Echinacea angustifolia root extracts on cancer cells: interference with doxorubicin cytotoxicity. Chemistry and Biodiversity. 2006;3:695-703.

30. Suffness M, Pezzuto JM. In Methods in Plant Biochemistry: Assays for Bioactivity. In: Hostettmann K, editor. London: Academic Press; 1990. p. $71-133$.

31. Whalen M, Loganathan B. Butyltin exposure causes a rapid decrease in cyclic amp levels in human lymphocytes. Toxicol Appl Pharmacol. 2001;171:141-148.

32. Yan Y, Li J, Han J, et al. Chlorogenic acid enhances the effects of 5flurouracil in human hepatocellular carcinoma cells through the inhibition of extracellular signal-regulated kinases. Anticancer Drugs. 2015;26(5):540-546. 
33. Groom S, Johns T, Oldfield P. The potency of immunomodulatory herbs may be primarily dependent upon macrophage activation. J Med Food. 2007;10(1):73-79.

34. Schwarz E, Parlesak A, Henneicke-von Zepelin H, et al. Effect of oral administration of freshly pressed juice of Echinacea purpurea on the number of various subpopulations of B- and T-lymphocytes in healthy volunteers: results of a double-blind, placebo-controlled cross-over study. Phytomedicine. 2005;2(9):625-631. 